\title{
Determining the Appropriate Emergency Planning Attributes for Microreactors
}

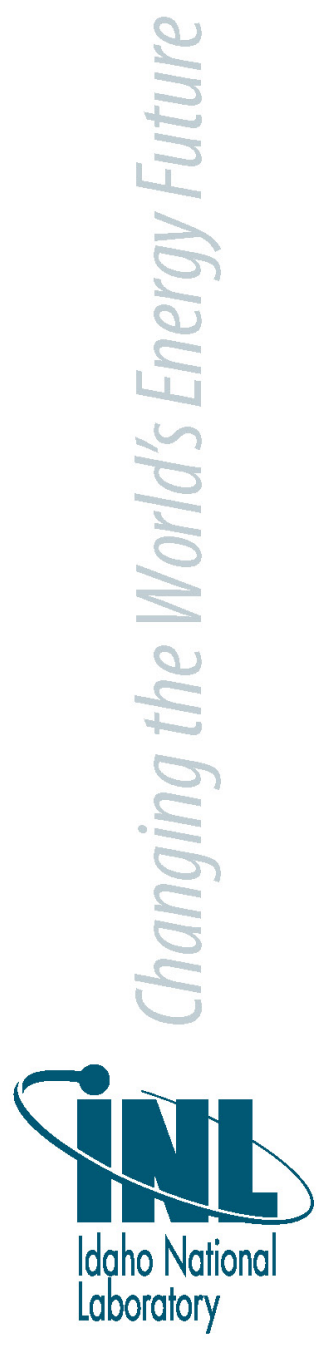

Jason Christensen

Peter Jordan

Wayne Moe 


\section{DISCLAIMER}

This information was prepared as an account of work sponsored by an agency of the U.S. Government. Neither the U.S. Government nor any agency thereof, nor any of their employees, makes any warranty, expressed or implied, or assumes any legal liability or responsibility for the accuracy, completeness, or usefulness, of any information, apparatus, product, or process disclosed, or represents that its use would not infringe privately owned rights. References herein to any specific commercial product, process, or service by trade name, trade mark, manufacturer, or otherwise, does not necessarily constitute or imply its endorsement, recommendation, or favoring by the U.S. Government or any agency thereof. The views and opinions of authors expressed herein do not necessarily state or reflect those of the U.S. Government or any agency thereof. 
INL/EXT-20-58467

Revision 0

\title{
Determining the Appropriate Emergency Planning Attributes for Microreactors
}

\author{
Jason Christensen \\ Peter Jordan \\ Wayne Moe
}

May 2020

\section{Idaho National Laboratory \\ Idaho Falls, Idaho 83415}

http://www.inl.gov

\author{
Prepared for the \\ U.S. Department of Energy \\ Office of Nuclear Energy \\ Under DOE Idaho Operations Office \\ Contract DE-AC07-05ID14517
}


Page intentionally left blank 


\section{EXECUTIVE SUMMARY}

Microreactor designs incorporate design features that provide very low reactor decay heat power at 24 hours after a shutdown that is manageable, in comparison with larger reactors. This attribute translates into a low probability of core damage and negligible offsite dose. This paper provides the conceptual framework for appropriately structuring emergency planning requirements for microreactors, while ensuring that the U.S. Nuclear Regulatory Commission's (NRC) commitment to safety is met. Due to the diversity in reactor designs throughout the microreactor community, this paper identifies the necessary concepts that should be considered to ensure that emergency plans for microreactors are appropriate for the risk. This paper does not mandate specific design features for microreactors but provides reactor designers a conceptual framework for a scalable, graded approach to emergency planning standards that should be considered in their individual designs in order to support simplified emergency plans.

Given that accident source terms associated with microreactors are essentially negligible when compared with those for large light-water reactors, revisions to emergency planning standards are justified. A graded approach to implementing emergency planning guidance can be used to appropriately structure microreactor emergency plans and reduce the size of the emergency planning zone and plume exposure pathway. Appropriately structuring emergency planning requirements will better optimize licensee and offsite agencies' emergency planning resources and reduce the resources associated with emergency planning. 
Page intentionally left blank 


\section{CONTENTS}

EXECUTIVE SUMMARY

ACRONYMS

vii

1. Introduction 1

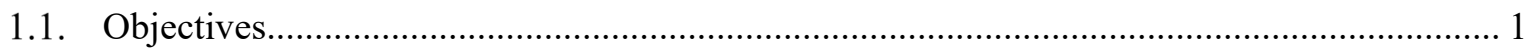

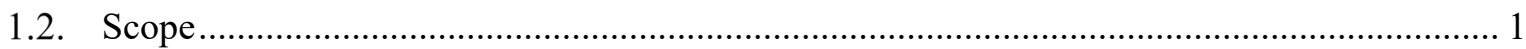

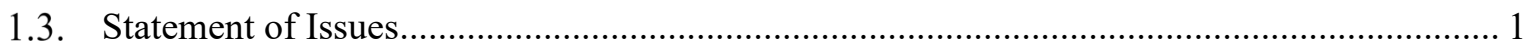

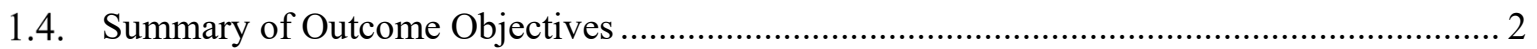

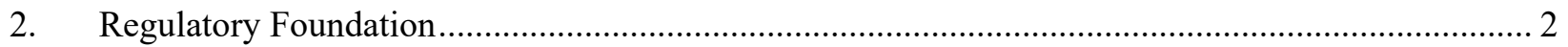

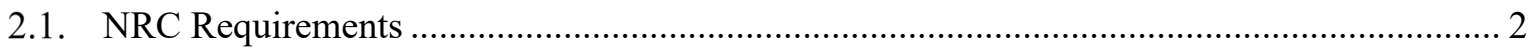

2.1.1. Glossary of Planning Zones Around a Nuclear Power Plant ..................................... 2

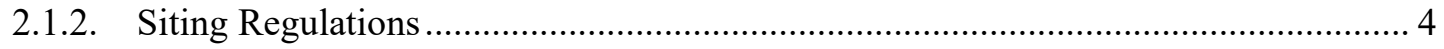

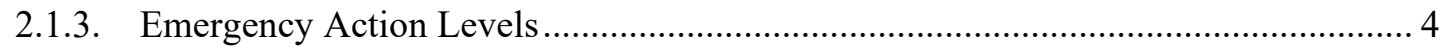

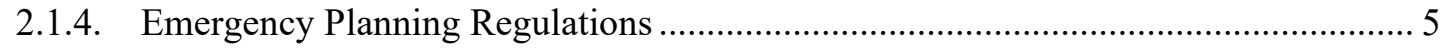

2.2. Environmental Protection Agency Protective Action Guides ............................................... 6

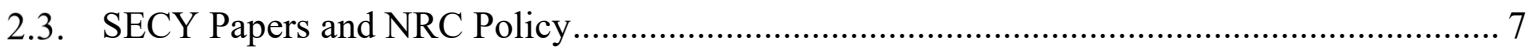

2.4. Proposed Rulemaking of 10 CFR 50.160 ....................................................................... 7

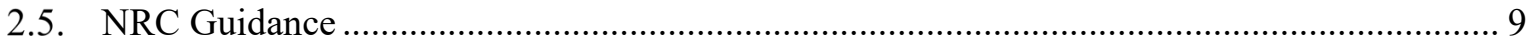

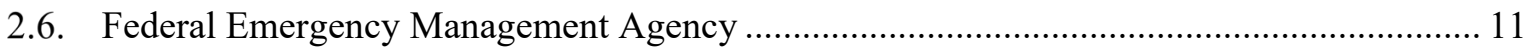

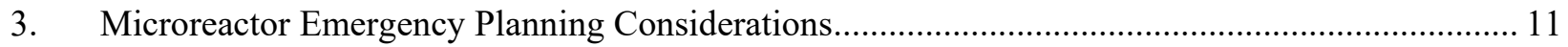

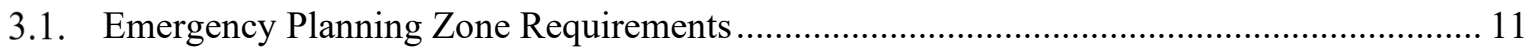

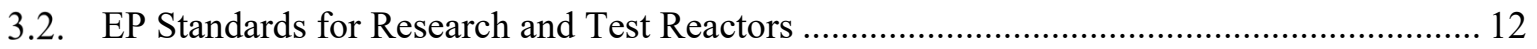

3.3. Analysis of Emergency Planning in the Oklo Aurora COLA ............................................. 12

3.4. Analysis of Emergency Planning Standards for Microreactors .......................................... 14

4. Summary of Proposed Microreactor Planning Standards .......................................................... 20

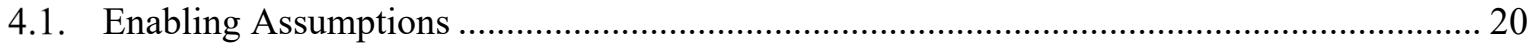

4.2. Changes to Regulatory Guidance and Requirements .................................................... 20

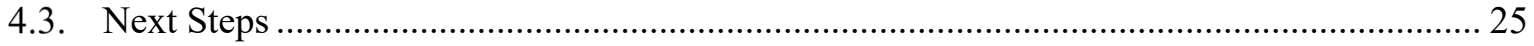

\section{FIGURES}

Figure 1. The zones around a Nuclear Power Plant........................................................................... 4

\section{TABLES}

Table 1. Suggested 10 CFR 50.47 Emergency Planning Standards for Microreactor Technologies.......... 21 
Page intentionally left blank 


\section{ACRONYMS}

COLA combined operating license application

CFR Code of Federal Regulations

EAB exclusion area boundary

EAL emergency action level

EOF Emergency Operations Facility

EP emergency plan

EPA Environmental Protection Agency

EPZ emergency planning zone

ERDS Emergency Response Data System

FEMA Federal Emergency Management Agency

FR Federal Register

ISG interim staff guidance

LPZ low population zone

LWR light-water reactor

NOUE Notice of Unusual Event

NRC U.S. Nuclear Regulatory Commission

ONT other nuclear technologies

PAG Protective Action Guide

REM roentgen equivalent man

RG Regulatory Guide

RTR research or test reactor

SMR small modular reactor

SRP Standard Review Plan

TEDE total effective dose equivalent

TSC Technical Support Center

UE unusual event 
Page intentionally left blank 


\section{Determining Appropriate Emergency Planning Standards for Microreactors}

\section{Introduction}

Microreactor technologies are currently being designed and developed to offer the nuclear industry a new, modern approach to providing electricity and industrial process heat. Multiple types of microreactors are being proposed, sharing similar size characteristics, limited quantities of radioactive material (i.e., a very small potential radiological source term), and low post-shutdown decay heat. Inherent and passive design features, along with highly autonomous operational characteristics, are being incorporated to further enhance reliability and public safety. Because microreactor designs are largely expected to preclude the possibility of significant offsite radiological consequences in the event of accident, it is proposed that changes be implemented to key current emergency preparedness (EP) requirements to reflect these different characteristics.

The purpose of this report is to examine current emergency planning regulations and associated guidance and propose alternative emergency planning standards concerning the installation and operation of commercial microreactors.

\subsection{Objectives}

Objectives of this paper include:

- Identify and summarize existing regulatory policy, guidance, and standards pertaining to EP as it applies to microreactor technology

- Identify and summarize key regulatory, technical, and policy issues relative to resizing an emergency planning zone (EPZ) scaled appropriately to microreactors

- Discuss key differences in microreactors EP needs when compared to existing light-water reactors

- Review important considerations for determining microreactor onsite and offsite emergency planning requirements [i.e. the 16 emergency planning standards of 10 CFR 50.47(b)]

- Propose alternative emergency planning standards for microreactors that may be considered for use by industry and regulatory stakeholders.

\subsection{Scope}

Regulatory requirements pertaining to plant siting, areas of owner control, and onsite and offsite planning zones have evolved over recent decades with a focus on large light-water reactor (LWR) power plants. Today's regulatory framework reflects decisions appropriate for large LWRs but does include allowances for small LWRs and non-LWRs. Multiple microreactor suppliers are pursuing submissions to the U.S. Nuclear Regulatory Commission (NRC) for standard design certification. One such microreactor design, the Oklo "Aurora" system, was submitted in early 2020. This design, as well as all subsequent microreactor concepts, will likely display characteristics of small reactor core sizes, passive accident mitigation features, lower power densities, very low decay heat, low or essentially no probability of severe accidents, slower accident progression, and small or negligible dose consequences both offsite and onsite. The microreactors included in this scope are generally considered to be $\leq 20 \mathrm{MW}_{\text {th }}$.

\subsection{Statement of Issues}

Current EP and Federal Emergency Management Agency (FEMA) regulations and guidance have not been updated to sufficiently reflect recent advances in advanced reactor (i.e., non-LWR) design safety. To address this concern, in 2015 the Commission approved an NRC staff's recommendation to initiate 
rulemaking to revise EP regulations as presented in SECY-18-0103 and guidance for small modular reactors (SMRs) and other nuclear technologies (ONT). In 2019, the Commission approved the NRC staff's proposed rulemaking discussed in SECY-18-0103 (known as 10 CFR 50.160) to create a new EP regulation for SMRs and ONTs. Microreactors are to be treated as a subset of this reactor population. This rulemaking is currently undergoing evaluation by affected stakeholders to ensure that microreactors are adequately addressed in the new regulations; this report will not focus on this evaluation but rather will examine issues associated with applications that may choose to use the 16 planning standards of 10 CFR 50.47(b) in their site EP program.

\subsection{Summary of Outcome Objectives}

The goal of this examination is to identify important emergency planning considerations for commercial microreactor $\left(\leq 20 \mathrm{MW}_{\text {th }}\right)$ deployment and operation; the focus of this review is on the 16 planning standards of 10 CFR 50.47(b) in the context of the proposed 10 CFR 50.160 rulemaking and to ensure that specific attributes of microreactor design, operation, and accident analysis and mitigation have been adequately addressed.

Current NRC requirements are structured to support large LWRs (e.g., $\geq 1,000 \mathrm{MW}_{\text {th }}$ in power rating); these units can present significant consequences to the health and safety of the public and environment in the event of an accident. Microreactor design and operation, on the other hand, are display smaller reactor core sizes, passive accident mitigation features, lower power densities, lower probability of severe accidents, slower accident progression, and smaller dose consequences both offsite and onsite. This can therefore lead to substantially reduced EPZ size, reduced onsite and offsite emergency planning response requirements, and reduced numbers of response staff.

Regulatory requirements that may warrant modification and update for the purposes of microreactor emergency planning are addressed in Section 3. A description of the proposed rule 10 CFR Part 50.160 is provided, but this report is intended to compliment this activity by instead focusing on the existing EP standards found in 10 CFR Part 50.47(b) for use on the microreactor technology class.

\section{Regulatory Foundation}

\subsection{NRC Requirements}

\subsubsection{Glossary of Planning Zones Around a Nuclear Power Plant}

Under current regulation, multiple areas or zones of planning are expected around a nuclear power plant. Reactor siting regulations in 10 CFR Part 100 specify two zones, defining these as:

Exclusion area means that area surrounding the reactor, in which the reactor licensee has the authority to determine all activities including exclusion or removal of personnel and property from the area. This area may be traversed by a highway, railroad, or waterway, provided these are not so close to the facility as to interfere with normal operations of the facility and provided appropriate and effective arrangements are made to control traffic on the highway, railroad, or waterway, in case of emergency, to protect the public health and safety. Residence within the exclusion area shall normally be prohibited. In any event, residents shall be subject to ready removal in case of necessity. Activities unrelated to operation of the reactor may be permitted in an exclusion area under appropriate limitations, provided that no significant hazards to the public health and safety will result. 
Low population zone means the area immediately surrounding the exclusion area which contains residents, the total number and density of which are such that there is a reasonable probability that appropriate protective measures could be taken in their behalf in the event of a serious accident. These guides do not specify a permissible population density or total population within this zone because the situation may vary from case to case. Whether a specific number of people can, for example, be evacuated from a specific area, or instructed to take shelter, on a timely basis will depend on many factors such as location, number and size of highways, scope and extent of advance planning, and actual distribution of residents within the area.

Emergency planning regulations in 10 CFR Part 50 also identify two zones. Unlike siting zones, the definition of the EPZs is not specified exactly in the regulations but can be summarized from guidance documents, notably NUREG-0396. Accordingly, these zones are shown in Figure 1 and are as follows:

Plume exposure pathway EPZ for nuclear power reactors shall consist of an area about 10 miles $(16 \mathrm{~km})$ in radius. The principal exposure sources from this pathway are (a) whole body external exposure to gamma radiation from the plume and from deposited material and (b) inhalation exposure from the passing radioactive plume. The time of potential exposure could range from hours to days.

Ingestion pathway $\mathbf{E P Z}$ shall consist of an area about 50 miles $(80 \mathrm{~km})$ in radius. The plans for the ingestion pathway shall focus on such actions as are appropriate to protect the food ingestion pathway. The principal exposure from this pathway would be from ingestion of contaminated water or foods such as milk or fresh vegetables. The time of potential exposure could range in length from hours to months.

Used, but not defined in security regulations, is the term "owner-controlled area". This term is generally interpreted to be equivalent to the exclusion area required by 10 CFR Part 100 . 


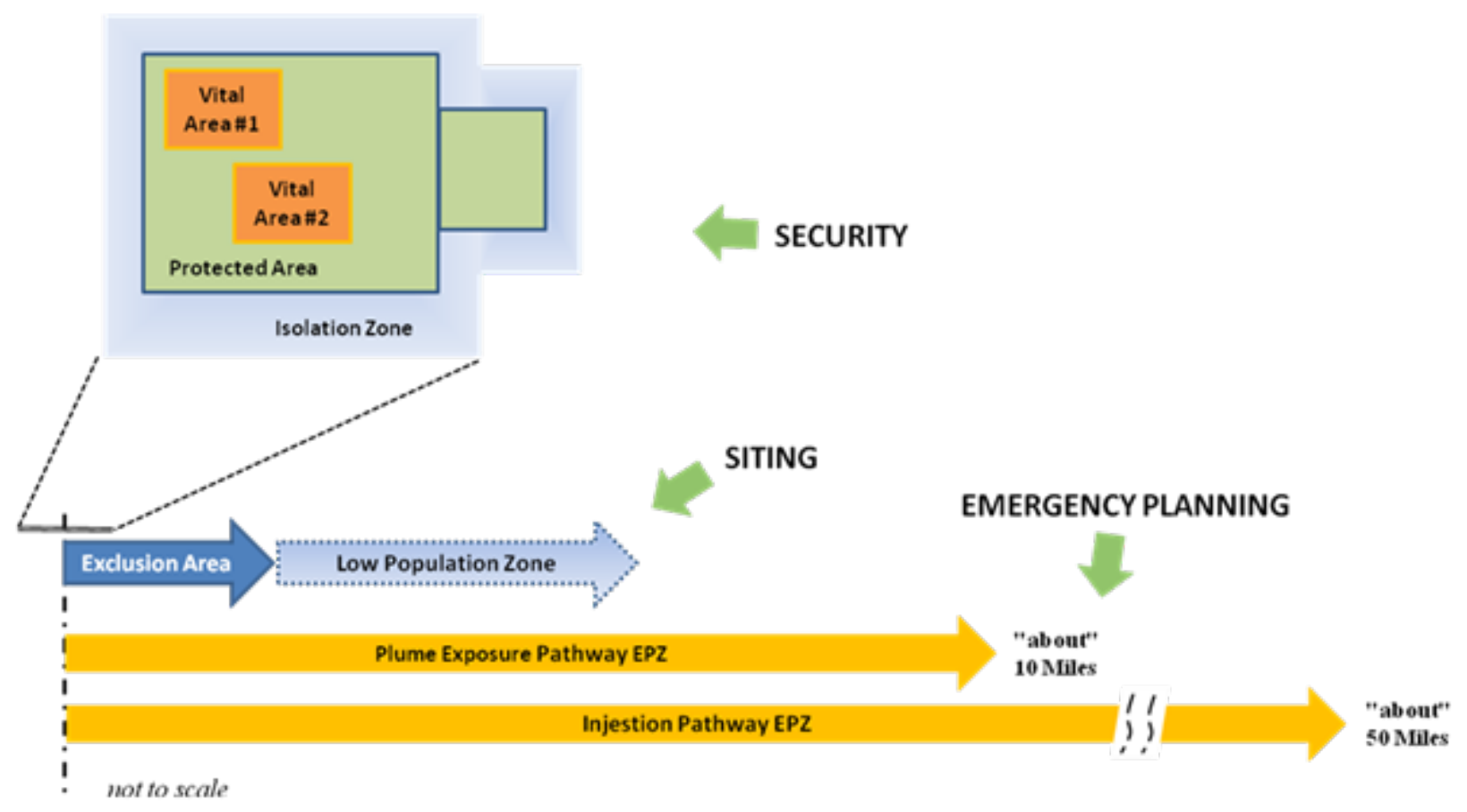

Figure 1. The zones around a Nuclear Power Plant.

\subsubsection{Siting Regulations}

Considerations for the acceptable implementation of site suitability requirements for nuclear power stations are described in Regulatory Guide (RG) 4.7, R3, "General Site Suitability Criteria for Nuclear Power Stations," (March 2014). The guide discusses the major site characteristics related to public health and safety and environmental issues for determining the suitability of sites for LWR nuclear power stations. It does not provide separate regulatory requirements for ONTs, SMRs, or microreactors. Presumably though, these same site considerations would be applicable to the evaluation of any planned nuclear facility.

A reactor licensee is required by 10 CFR 100.21(a) to designate an exclusion area and to have the authority to determine all activities within that area. In addition, the licensee is required to designate an area immediately surrounding the exclusion area as a low population zone (LPZ). The LPZ is required to be of such size that an individual located on its outer boundary during the postulated accident would not receive a radiation dose in excess of a 25- roentgen equivalent man (REM) total effective dose equivalent (TEDE). The size of the LPZ depends, in part, on aspects of the plant design.

Because of potential differences in the SMR and ONT designs, the proposed rule 10 CFR Part 50.160 does not contain an evaluation of a generic type of plant. Instead, SMR and ONT applicants will develop their EPZ sizes based on the accident source terms, fission product releases, and accident dose characteristics for the specific plant design. The recommended analyses, as documented in "Required Analyses for Informing Emergency Planning Zone Size Determinations" (dated June 2018), will be performed in conjunction with the criterion that the EPZ should encompass the area where the public would receive a post-accident dose of 1 REM or more over 96 hours.

\subsubsection{Emergency Action Levels}

10 CFR 50, Appendix E, Section IV, "Content of Emergency Plans", paragraph B, mandates that emergency plans must contain "emergency action levels (EALs)." These may also be termed "emergency classes." They are used for the grouping of off-normal events or conditions according to (1) potential or 
actual effects or consequences and (2) resulting onsite and offsite response actions. There is no prescriptive guidance for the development of EALs, but rather they are developed by the technology designer based on the anticipated radiological consequence of progressive off-normal plant events; NRC agreement is required for this approach to be accepted in licensing actions. EALs are used for (1) determining the need for notification to and participation of various agencies and (2) determining when and what type of protective measures should be considered. The four current EALs, in ascending order of severity, are:

- $\quad$ Notification of Unusual Event (NOUE, sometimes abbreviated as UE)

- Alert

- Site Area Emergency

- General Emergency

These EALs apply to both nuclear power plants and research and test reactors of any power level. Declarations by the licensee of any EAL requires notifications made to the NRC and offsite organizations, as applicable.

\subsubsection{Emergency Planning Regulations}

Appendix E to Part 50 requires that each reactor license applicant provide plans for coping with emergencies in order to comply with 50.34 or 52.79. NRC Regulatory Guide 4.7, revision 2, "General Site Suitability Criteria for Nuclear Power Stations, March 2014," states that adequate plans must be developed for two areas (or EPZs): the plume exposure pathway and the ingestion pathway. As stated in 10 CFR 50.47, these EPZs for nuclear power plants are generally established at radii of 10 miles and 50 miles, respectively. This requirement exists as a result of context applicability to large LWR power facilities. Comparable requirements sized for very small reactor facilities are not addressed. However, both 10 CFR 50.33(g) and 50.47(c)(2) allow for the size of the EPZ to be determined on a case-by-case basis for reactors with an authorized power level of less than $250 \mathrm{MW}_{\text {th }}$.

As described in NUREG-0654 R2, NUREG-0396 established the technical basis for the 10 mileradius plume exposure pathway and the 50 mile-radius ingestion exposure pathway applicable to a conventional large LWR. Over the years, however, there have been licensing actions for smaller commercial reactors, research reactors, and fuel storage facilities that allowed for smaller EPZs or removed the need for an EPZ beyond the site boundary, based upon the Environmental Protection Agency (EPA) Protective Action Guides (PAGs).

The operations and risk associated with microreactors and their low potential accident hazards may be more closely related to small research and test reactors and their low thermal output. RG $2.6 \mathrm{R} 2$ presents guidance for developing emergency plans for research and test reactors in accordance with 10 CFR 50, Appendix E requirements. Appendix E notes that potential radiological hazards to the public associated with research and test reactors involve different considerations than those associated with larger nuclear power reactors. The RG applies to research and test reactors and other nonpower facilities under 50.21 for Class 104 licenses. RG 2.6 also applies to commercial and industrial facilities under 50.22 for Class 103 licenses. However, as additionally provided in Part 50.22,

a facility is deemed to be for industrial or commercial purposes if the facility is to be used so that more than 50\% of the annual cost of owning and operating the facility is devoted to the production of materials, products, or energy for sale or commercial distribution [emphasis added], or to the sale of services, other than research and development or education or training.

Microreactors are expected to fall into this category and, presumably, would therefore be licensed in accordance with Part 50.22. 


\subsection{Environmental Protection Agency Protective Action Guides}

The EPA has developed PAG Manual (EPA-400R-17/001, January 2017) to assist public officials in

planning emergency responses to radiological incidents, which could release radioactive materials into the environment in quantities that warrant protective action. A PAG is defined as the projected radiological dose to an individual at which a specific protective action to reduce or avoid that dose is recommended. NUREG-0396 and EPA-400 identified the PAG dose guidelines of 1 rem to the whole body and 5 rem to the thyroid as doses at which public protective actions should be undertaken. Specifically, NUREG-0396 states:

The concept of Protective Action Guides was introduced to radiological emergency response planning to assist public health and other governmental authorities in deciding how much of a radiation hazard in the environment constitutes a basis for initiating emergency protective actions. These guides (PAGs) are expressed in units of radiation dose (rem) and represent trigger or initiation levels, which warrant pre-selected protective actions for the public if the projected (future) dose received by an individual in the absence of a protective action exceeds the PAG. PAGs are defined or definable for all pathways of radiation exposure to man and are proposed as guidance to be used as a basis for taking action to minimize the impact on individuals.

The nature of PAGs is such that they cannot be used to assure that a given level of exposure to individuals in the population is prevented. In any particular response situation, a range of doses may be experienced, principally depending on the distance from the point of release. Some of these doses may be well in excess of the PAG levels and clearly warrant the initiation of any feasible protective actions. This does not mean, however, that doses above PAG levels can be prevented or that emergency response plans should have as their objective preventing doses above PAG levels. Furthermore, PAGs represent only trigger levels and are not intended to represent acceptable dose levels. PAGs are tools to be used as a decision aid in the actual response situation. Methods for the implementation of Protective Action Guides are an essential element of emergency planning. These include the predetermination of emergency conditions for which planned protective actions such as shelter and/or evacuation would be implemented offsite.

In the 1970's, the Joint NRC/EPA Task Force on Emergency Planning recommended that the PAGs be updated and used to structure a framework for offsite emergency response actions tied to a spectrum of postulated accidents from minor through severe (Class 9). PAGs are used to define the EPZs. The following criteria were used to determine the generic distance for the plume exposure pathway EPZ:

- The EPZ should encompass those areas in which the projected dose from design-basis accidents could exceed the EPA PAGs.

- The EPZ should encompass those areas in which consequences of less severe Class 9 (core melt) accidents could exceed the EPA PAGs.

- The EPZ should be of sufficient size to provide for the substantial reduction in early severe health effects in the event of the more severe Class 9 accidents.

The PAGs are critical for EP and are based on the dose at certain distances. Based on the intrinsic differences that are expected to be associated with microreactors and their minimal offsite event 
consequences, the PAGs could potentially demonstrate attainment with a significantly smaller EPZ, thus suggesting that the emergency planning standards may need a significant adaptation and update as a consequence of the downscaled EPZ.

\subsection{SECY Papers and NRC Policy}

SECY-11-0152, "Development of an Emergency Planning and Preparedness Framework for Small Modular Reactors," dated October 28, 2011, discusses the NRC staff intent to develop a technologyneutral, dose-based, consequence-oriented EP framework for SMR sites that accounts for design differences, modularity, and collocation with industrial facilities, as well as a scalable emergency planning zone size. This SECY paper again noted that the size of the EPZ could also be determined on a case-by-case basis for reactors with an authorized power level of less than $250 \mathrm{MW}_{\text {th }}$.

SECY-11-0152 discusses the implementation of 10 CFR 50.47(b)(11) requirements for compliance with exposure guidelines consistent with EPA PAGs. The current EPA PAG guidance provides that licensed facilities that can demonstrate that accident doses at the site boundary would not exceed the PAGs should not be required to have either defined EPZs or comprehensive offsite emergency planning. Although the guidance in NUREG-0396 and EPA-400 was written for large LWRs, the underlying principle of using dose savings to determine EPZ size should be applicable to small reactors.

As a policy issue, SECY-11-0152 states:

EP programs for SMR sites should address implications of a smaller source term and passive design features associated with SMRs. One approach could be to have offsite EP requirements scaled to be commensurate with the SMR accident source term, fission product release, and associated dose characteristics, which are all a function of the licensed reactor power level.

If projected accident offsite doses are less than 1 rem at the site boundary, then no EPZ beyond the site boundary would be required and the offsite emergency planning requirements would be limited. Specific EP requirements would be commensurate with the size of the EPZ . . based on offsite dose.

The NRC is initiating a rulemaking to address EP requirements and address considerations for reactor types other than large LWRs (Docket ID: NRC-2015-0225). When completed, this rulemaking would establish a new 10 CFR 50.160.

\subsection{Proposed Rulemaking of 10 CFR 50.160}

In December 2019, the NRC published a proposed rulemaking for emergency planning that can be invoked by allowing an applicant to choose between 10 CFR 50.160 and the emergency plan requirements found in Appendix E to 10 CFR 50 (including the planning standards found in $10 \mathrm{CFR}$ $50.47(\mathrm{~b})$ ). This proposed rule is a performance-based, technology-inclusive, risk-informed, and consequence-oriented approach to emergency planning for SMRs and ONTs. As a performance-based approach, this proposed rule will provide a basis for EP through the review of design- and site-specific accident scenarios. This varies significantly from the previous deterministic approach of Appendix E and 10 CFR 50.47(b). The technology-inclusive approach allows for design considerations of each specific design to be considered in the development of an emergency plan. This includes passive safety characteristics, new fuel types, and other processes that enhance safety within the designs. This will create different plans for each design but will allow reactor applicants to fully utilize the specific safety features of their design. As a risk-informed and consequence-oriented approach, this proposed rule will focus on the level and severity of consequences related to a credible accident. Being risk-informed rather than risk-based allows emergency planning to be more independent of accident probability. Guidance for this proposed rule would be found in DG-1350, "Performance-Based Emergency Preparedness for Small 
Modular Reactors, Non-Light-Water Reactors, and Non-Power Production or Utilization Facilities" (ADAMS ML18082A044).

The alternative EP requirements would also adopt a new, scalable plume exposure pathway EPZ. According to the NRC, the new alternate requirements of 10CFR 50.160 will reduce the number of exemption requests from EP requirements, promote regulatory clarity and stability, and provide a reasonable assurance that SMR or ONT licensees will implement adequate protective measures. Also, this proposed rule would credit safety enhancements built into the advanced designs as well as credit the smaller size and benefits of these reactors associated with postulated accidents.

Another major provision of this proposed rule and guidance would be an alternative, performancebased framework that will be detailed in 10 CFR 50.160. This performance-based framework would include (1) the demonstration of emergency response functions through the development and maintenance of performance objectives and regular drills and exercises, (2) on- and offsite planning activities, (3) the consideration of credible hazards associated with collocated NRC-licensed and non-licensed industrial facilities, and (4) a required description of the boundary and physical characteristics of the plume exposure pathway EPZ and ingestion response planning capabilities. This proposed rule places focus on the actual performance of drills and exercises rather than control of emergency plans.

Each applicant/licensee is anticipated to have performance-based requirements that would be specific to the design of the plant. The NRC may need to develop additional guidance to cover the specifics of each design. Performance objectives would be developed and maintained by calendar quarter, and the NRC would review the objectives and metrics as well as use them during routine and periodic inspections to ensure that the licensee is maintaining adequate emergency planning and preparedness.

One major benefit to microreactor applicants of the proposed rule is the scaled EPZ. For instance, facilities with EPZs that do not extend beyond the site boundary would not be required to include tribal, state, and local government organizations in radiological drills and exercises. However, applicants/licensees would still be required to establish an emergency classification system to determine the need for notification of offsite response organizations. The licensee/applicant would be required to demonstrate the assessment, classification, monitoring, and repairs to facility malfunctions, including returning the facility to a safe condition.

Licensees and applicants would also be required to demonstrate protective actions; communications to the emergency response staff, NRC, and offsite response organizations; and ensure a continuity of operations through shift changes and other potential staff issues. Staffing should be sufficient to respond to all emergency conditions and perform necessary tasks until the augmenting staff arrives onsite. The licensee/applicant will also have the ability to assess and monitor radiological conditions, including personnel contamination, radiological releases, and the early indication of loss of adequate core cooling. Finally, the licensee/applicant would need to show the ability to reenter the plant, move people in and out of the plant, and perform operations to secure the plant. Critiques of these drills and exercises (or responses to actual emergencies) should be performed to ensure that the performance of emergency response functions would be evaluated for areas of improvement. Deficiencies would be tracked through a corrective action program.

Applicants and licensees subject to the "Emergency Response Data System" ([ERDS], as identified in Appendix E to 10 CFR 50, Section VI) would be responsible for identifying the data links with NRC and OROs as required. ERDS capabilities would be reviewed for each applicant. No changes are proposed to the ERDS regulations.

This proposed rule for Emergency Planning on SMRs and ONTs will continue to be developed and eventually codified in 10 CFR 50.160, but this report will strictly focus on utilizing and modifying current standards under 10 CFR 50.47(b) for use in microreactors. 


\subsection{NRC Guidance}

The NRC has endorsed multiple guidance documents to assist applicants in developing EPs to address regulatory requirements. While using such guidance is generally not required and applicants can choose other alternatives to address regulatory requirements, utilizing established regulatory guidance does help ensure that all requirements are met in a way the staff will find acceptable, thereby increasing confidence and improving regulatory review efficiency. It is important to remember, however, that existing EP guidance was written largely for large light-water reactors and SMRs and ONTs.

Regulatory requirements associated with the siting and design of nuclear facilities are promulgated in 10 CFR 100, "Reactor Siting Criteria," 10 CFR 50, "Domestic Licensing of Production and Utilization Facilities," and 10 CFR 52, "Licenses, Certifications, and Approvals for Nuclear Power Plants." Part 52 applications are required to include general information, as required under 10 CFR 50.33. Each facility must have a defined exclusion area and LPZ as defined by 10 CFR 100.3 and 10 CFR 50.2.

10 CFR 50.34(a)(10) requires facility applications to plan for coping with emergencies; 10 CFR 50, Appendix E sets forth items to be included in these plans.

10 CFR 50.33(g) and 50.47(c)(2) establishes general EPZ size for power reactors as 10 miles for the plume exposure pathway and 50 miles for the ingestion exposure pathway. However, for reactors of power levels less than $250 \mathrm{MW}_{\text {th }}$, the EPZ size may be determined on a case-by-case basis.

The onsite and offsite emergency response plans for nuclear power reactors must meet the 16 emergency plan planning standards set forth in 10 CFR 50.47(b).

\section{ISG-029}

On February 26, 2020, the NRC published draft interim staff guidance (ISG 029), "Environmental Considerations Associated with Microreactors," for public comment (85 Federal Register (FR) 11127). This draft guidance (ML20054B832) sought to assist NRC staff in determining the scope and scale of environmental reviews of microreactor applications. While this action is not specifically directed at emergency planning for microreactors, ISG 029 does provide insights into the NRC consideration of microreactor issues that may be associated with emergency planning. For example, it acknowledges that:

- Microreactor applications include a number of deployment purposes, such as power generation or industrial applications, potable water, hydrogen production, etc.

- Very small advanced reactor designs may have limited or zero radiological releases during normal operations

- Risks from accidents may be limited

- Some designs may not have credible severe accidents associated with it.

\section{NUREG-0396}

The concept of EPZs and their incorporation into the requirements and guidance for nuclear power plants emergency planning was introduced in NUREG-0396, "Planning Basis for the Development of State and Local Government Radiological Emergency Response Plans in Support of Light Water Nuclear Power Plants" (NRC 1978). NUREG-0396 discusses generic EPZs "as a basis for the planning of response actions, which would result in dose savings in the environs of nuclear facilities in the event of a serious power reactor accident." The nominal EPZ size was generally selected as 10 miles for the plume exposure pathway and 50 miles for the ingestion exposure pathway; these were chosen in order to assure that EPA PAGs would not be exceeded, based on the characteristics of a design basis and severe accident consequences associated with large LWRs.

As was noted in Section 1.4 of this paper, microreactor design and operations are anticipated to differ markedly from large LWRs by including a much smaller reactor core size, passive accident mitigation 
features, lower power densities, lower to potentially no probability of severe accidents, slower accident progression, and much smaller dose consequences to both offsite and onsite populations. These factors should justify a substantially reduced EPZ size than was envisioned in NUREG-0396. Along with a reduced EPZ size, fewer onsite and offsite emergency planning response requirements and response staff are needed, making EP needs more consistent with the power levels and risks associated with research and test reactors. Therefore, the EPZ size as described in NUREG-0396 would not be appropriate. As provided by $50.33(\mathrm{~g})$ and $50.47(\mathrm{c})(2)$, for reactors of power levels less than $250 \mathrm{MW}$ th, a different EPZ size may be determined on a case-by-case basis. Given that EPZs for microreactors are not expected to extend beyond the facility exclusion area, it is appropriate to presume that the need for substantive offsite emergency planning responses will not be required as well as substantially reducing the onsite emergency planning response needs.

\section{Regulatory Guide 1.101}

RG 1.101, "Emergency Response Planning and Preparedness for Nuclear Power Reactors, R-5, June 2005," provides guidance for complying with the requirements of 10 CFR 50 and Appendix E to Part 50 with respect to emergency planning and preparedness. It endorses NUREG-0654/ FEMA-REP-1, "Criteria for Preparation and Evaluation of Radiological Emergency Response Plans and Preparedness in Support of Nuclear Power Plants, R-2," and includes guidance for collocated facilities. Although not specifically stated in RG 1.101, this guidance is also structured to address emergency planning requirements for large LWRs rather than reactors of substantially lower power levels. It does specifically state, however, that applicants

\section{"... are free to propose other means to achieve compliance with applicable regulations."}

\section{NUREG-0654}

As noted above, NUREG-0654 provides criteria for compliance with emergency planning and preparedness requirements. It endorses the EPZ concept from NUREG-0396 with the caveat that the 10and 50-mile EPZs are applicable to LWRs rated at $250 \mathrm{MW}_{\text {th }}$ or greater. This acknowledges and introduces the concept that emergency planning requirements may be scaled for smaller reactors but does not provide any quantitative guidance.

\section{Regulatory Guide 4.7}

RG 4.7, "General Site Suitability Criteria for Nuclear Power Stations, R-3, March 2014," describes a method that the NRC considers acceptable to implement the site suitability requirements for nuclear power plants. It discusses major site characteristics related to public health and safety and environmental issues that the staff considers in determining site suitability for LWR facilities. It notes that adequate plans must be developed for the 10-mile plume exposure pathway and the 50-mile ingestion exposure pathway. This guidance is focused on the needs of large LWR facilities and does not address facilities of very small power output.

\section{NUREG-0800}

NRC's Standard Review Plan (SRP) for nuclear power plant applications, including early site permits and Combined Operating License Applications (COLs), is provided in NUREG-0800, "Standard Review Plan for the Review of Safety Analysis Reports for Nuclear Power Plants - LWR Edition." Section 13.3, "Emergency Planning, R-3, March 2007," describes the areas of review and acceptance criteria for emergency planning as described in the applicant's safety analysis report. In particular, reviews are made against the requirements of 10 CFR 50.47 and 10CFR 50 Appendix E, which establish requirements for emergency preparedness. As noted in SRP acceptance criteria, onsite and offsite emergency response plans must meet the standards established in 10 CFR 50.47(b) and applicable requirements of Appendix E 
to Part 50. Compliance with these regulations is determined by using the guidance of RG 1.101, R-2, which endorses NUREG-0654 and, through it, NUREG-0396 and NUREG-0696.

\subsection{Federal Emergency Management Agency}

As described in NUREG-0654/FEMA-REP-1, R2, "Criteria for Preparation and Evaluation of Radiological Emergency Response Plans and Preparedness in Support of Nuclear Power Plants, December 2019," both the NRC and FEMA evaluate the adequacy of emergency plans that pertain to offsite organizations such as state, local, and tribal governments within the EPZs surrounding commercial nuclear power plants. The evaluation criteria of this document address those elements and attributes of emergency plans and preparedness programs that are directly tied to meeting the planning standards in 10 CFR 50.47(b) and 44 CFR 350.5(a) and, for the NRC, are also used to assess compliance with 10 CFR 50, Appendix E.

If the NRC determines that the assurance of offsite radiological EP is not required for specific facilities where the EPZs do not extend beyond the site boundary, then FEMA determinations regarding reasonable assurance under 50.54(s)(3) would likely not be needed. The only offsite actions to be performed would be those associated with a community general response capability, which are not unique to radiological emergency response, e.g. fire, medical, law enforcement. Facility designers and license applicants will need to establish appropriate credible accident source terms, fission product release, and associated dose characteristics in order to establish a scaled approach for EP for the design and operation of the plant under consideration.

\section{Microreactor Emergency Planning Considerations}

\subsection{Emergency Planning Zone Requirements}

As stated in the regulatory basis for the proposed "Rulemaking for Emergency Preparedness for Small Modular Reactors and Other New Technologies" (docket ID: NRC-2015-0225), the technical basis for establishing scaled EPZ sizes are outlined in current power reactor and nonpower guidance NUREG0396, "Planning Basis for the Development of State and Local Government Radiological Emergency Response Plans in Support of Light Water Nuclear Power Plants (December 1978).” As already discussed, NUREG-0396 information has been used to establish fixed-radius EPZ requirements for large LWRs at 10 miles (plume exposure pathway EPZ) and 50 miles (ingestion exposure pathway EPZ); these EPZs have been incorporated into Appendix E to Part 50. A footnote also recognized that reduced EPZs may be appropriate for reactors with smaller authorized power levels of less than $250 \mathrm{MW}_{\text {th }}$ for which the EPZ may be determined on a case-by-case basis (but only referred to gas-cooled reactors). A similar rationale should be applicable for small microreactors with authorized licensed power levels up to 20 $\mathrm{MW}_{\text {th. }}$.

With the recent advent of small, non-LWR designs, SECY-11-0152, "Development of an Emergency Planning and Preparedness Framework for Small Modular Reactors," discusses the NRC staff's intent to develop a technology-neutral, dose-based, consequence-oriented EP framework suited to small modular reactor sites that accounts for variation in design approach, modularity, and potential collocation with nonregulated energy users. The SECY also notes that resized EPZs may accompany this requirement update. However, the staff's discussion in SECY-11-0152 does not specifically address the very small size and very low power levels anticipated for microreactor designs or their potentially unique operating characteristics.

As a policy issue presented in SECY-11-0152,

"EP programs for SMR sites should address the implications of a smaller source term and passive design features associated with SMRs." 
This paper suggests that this consideration be further developed and applied to microreactor designs as a subset of SMRs. Offsite EP requirements should be scaled to be commensurate and appropriate with the source terms, fission product release, and associated dose characteristics that are characteristic and attributable to microreactor technology. As stated in SECY-11-0152,

"The revised EPA PAG guidance (issued in 1992 as EPA-400-R-92-001) provides that licensed facilities that can demonstrate that accident doses at the site boundary would not exceed the PAGs should not be required to have either defined EPZs or comprehensive offsite emergency planning."

This consideration can support offsite EP requirements scaled to be commensurate with microreactor source term, fission product release, and associated dose characteristics.

\subsection{EP Standards for Research and Test Reactors}

NRC RG 2.6 and NUREG-0849 provide information on the EP standards for use in research and test reactors (RTR). These standards differ significantly from the EP standards for commercial power reactors under 10 CFR 50.47(b). Specifically, RG 2.6 states

"From its review of safety analysis reports for research and test reactors and other non-power production and utilization facilities, and based on the radionuclide inventory and postulated radioactive releases at these facilities, the $N R C$ staff determined that the potential radiological hazards to the public associated with the operation of these facilities are less than those associated with the operation of commercial nuclear power plants."

Since microreactors are similarly sized to RTRs, one might consider the application of separate planning standards as defined in NUREG-0849. However, RTR operating characteristics and their use in commercial power generation and industrial applications would likely involve different deployment and public risk issues that effectively preclude them from being assigned into this category. Relatedly, commercial power microreactors would be included in Class 103 licenses as defined by 10 CFR 50.22 for commercial and industrial facilities. As defined by 50.22,

such a facility is deemed to be for industrial or commercial purposes if the facility is devoted to the production of materials, products, or energy for sale or commercial distribution, or to the sale of services, other than research and development or education or training.

As such, microreactors are expected to fall within this regulated facility class. This report will therefore presume alternative requirements to existing EP requirements for large light-water reactors will be necessary rather than seek regulatory treatment as an RTR.

\subsection{Analysis of Emergency Planning in the Oklo Aurora COLA}

In March 2020, Oklo Power, LLC. submitted a combined operating license application (COLA) to the NRC for a new microreactor concept. This single-digit-megawatt-power commercial fast reactor design was designated Aurora and, at this time, NRC is performing acceptance reviews of the submission in advance of regulatory safety evaluations and determinations of adequate safety. A public version of the COLA is available under NRC Docket No. 99902046 and is on the NRC website under ADAMS Accession No. ML20075A000.

Aurora is the first very small nuclear power design to seek an NRC license to build and operate a commercial microreactor. In its COLA documentation, Oklo describes Aurora as inherently safe with no reliance on secondary systems, electricity, or human action to maintain safety. The safety approach discussed in the COLA is predicated on a maximum credible accident risk analysis derived from extensive examinations of a spectrum of internal and external events. Safety is presumed inherent in large 
part due to its very small size, small radionuclide inventory, low power density, low fuel burnup, a robust fuel design, and cooling systems that are independent of the presence of water. Aurora developers believe there is no credible radiological release scenario (see Chapter 5 of Part II of the COLA) that is associated with the design. The safety analysis discussed in the COLA submission is reflected in discussions of projected EP needs.

Part VII of the COLA contains key supporting documents and plans for Aurora. Enclosure 3 of Part VII specifically addresses the emergency planning proposed for the design (see NRC ADAMS Accession No. ML18134A086). The following are key highlights of this discussion relative to microreactor-oriented EP standard development.

The stated objective of the Aurora emergency planning is to provide defense-in-depth protection for the reactor unit and onsite personnel. Because design safety was determined by the supplier to preclude the need for substantive offsite emergency planning (as is required of the current LWR fleet), EP is proposed to comply with only the applicable onsite aspects of Title 10 of the Code of Federal Regulations Part 50 (10 CFR 50) Section 50.47, "Emergency Plans," and applicable onsite regulations in 10 CFR 50 Appendix E, "Emergency Planning and Preparedness for Production and Utilization Facilities."

Important characteristics of the Aurora emergency planning include:

1. Organization and Responsibilities: A Plant Manager will oversee various plant monitors assigned to track reactor parameters and assure site security. Since the Manager will often be absent from the site during normal operations, site monitors will be relied upon to track key parameters and initiate reactor trips when warranted. During plant emergencies, these staff will transition into emergency operations roles projected as necessary for plant-level response. Because of the safety attributes associated with the design, the supplier proposes that emergency response pathways emphasize communications with community emergency response organizations (especially those related to fire, medical, and security capabilities), as well as with the NRC.

2. Emergency Classification: Emergency types are classified based on credible reactor events and other emergency situations that require appropriate levels of emergency response. Existing regulations outline four classes of emergency conditions event groups, based on their relationship to potential offsite radiological consequences (See Section 2.1.3 for further discussions on event classification). Aurora developers believe no credible emergency event exists that can lead to a consequence greater than the least severe existing class of event (i.e., the NOUE). A NOUE could be initiated at an Aurora installation by either manmade events or natural phenomena that creates a hazard that did not previously exist. Because no radioactive material release requiring offsite response are postulated, the remaining three notification levels (i.e., Alert, Site Area Emergency, and General Emergency) are not considered credible and are not applicable.

3. Emergency Action Levels: The Aurora supplier believes no credible site emergency can produce exposures beyond the site boundary in exceedance of EPA PAGs for projected site dose. On this basis, an offsite radiological response capability is unnecessary.

4. Emergency Planning Zone: The plume exposure and ingestion exposure pathway comprise the same EPZ for Aurora, which is limited to the exterior boundary of the Aurora powerhouse. As there will be no radiological releases associated with the maximum credible accident, the PAGs are met through an EPZ limited to the Aurora powerhouse, thereby eliminating the need to establish an offsite emergency planning zone response capability. Consequently, parts of $10 \mathrm{CFR}$ 50.47 and 10 CFR Part 50, Appendix E related to offsite emergency monitoring and response would no longer serve the underlying the intent of the regulation by ensuring a rapid response to protect the public in the case of an offsite radiological event.

5. Emergency Facilities and Equipment: A "monitoring room" is to be designated in the powerhouse where the onsite alarm station and emergency support center will be established. In 
the event a site evacuation is needed, a preselected location outside the powerhouse will be designated as an Emergency Operations Facility and be available to coordinate facility assessments, response, and recovery activities.

6. Maintaining Emergency Preparedness: Plant personnel assigned EP duties will be trained commensurate with their role and decision-making responsibilities. Drills will be regularly conducted to test emergency response equipment and staff proficiencies. Training drills for radiological releases beyond the site boundary are deemed unnecessary and will not be performed. Emergency plans will be annually updated, and equipment inspections and calibrations regularly performed.

At this time, NRC has not provided opinions or determinations concerning the adequacy of these proposed emergency planning attributes. However, in order to request regulatory acceptance of the generic Aurora Emergency Plan, exemptions were requested by the developer in accordance with $10 \mathrm{CFR}$ 50.12. As is stated in Part V of the COLA, "Non-Applicabilities and Requested Exemptions," (see ADAMS Accession No ML20075A006), exemptions sought in this regard include:

- 10 CFR 50.47(b), in part

- $\quad 10$ CFR 50.47(b)(4), in part

- $\quad 10$ CFR 50.47(b)(6), in part

- $\quad 10$ CFR 50.47(b)(7)

- $\quad 10$ CFR 50.47(b)(9)

- 10 CFR Part 50, Appendix E, Section IV.E.8.b

- 10 CFR Part 50, Appendix E, Section IV.F.1, in part

- 10 CFR Part 50, Appendix E, Section VI.1, in part

- 10 CFR Part 50, Appendix E, Section VI.2.a, in part

- 10 CFR Part 50, Appendix E, Section VI.3.d, in part

Further information on the technical and regulatory basis for requesting these exemptions can be found in Section 3.6 of Part V of the COLA.

\subsection{Analysis of Emergency Planning Standards for Microreactors}

As is discussed in Section 2.4, alternative EP requirements are being proposed that would be scaled and applicable to smaller classes of reactors. Microreactors are not explicitly identified or discussed in this rulemaking initiative but, based upon anticipated maximum power levels $\left(\leq 20 \mathrm{MW}_{\text {th }}\right)$, would likely be included in ONTs.

To be maximally effective and efficient, microreactor EP requirements should be scalable (perhaps as a function of their licensed power levels), be performance-based, and strongly oriented towards potential consequences, while taking into account the unique design characteristics, expected safety enhancements, and potential for slower accident progression. Changes to the 16 planning standards of 50.47(b) will be necessary to meet this objective. Issues and concerns related to these changes are discussed below according to each standard as it relates to microreactor technologies:

EP Standard 10 CFR 50.47(b)(1)

Primary responsibilities for emergency response by the nuclear facility licensee and State and local organizations within the Emergency Planning Zones have been assigned, the emergency responsibilities of the various supporting organizations have been specifically established, and each principal response 
organization has staff to respond and to augment its initial response on a continuous basis.

Discussion:

The emergency plan should describe the functions, as applicable, to the emergency planning of federal, state, and local government agencies and the assistance that they would provide in the event of an emergency.

The very low power level associated with microreactors, negligible potential source terms, enhanced passive and automated response safety features likely to be demonstrated in association with microreactors should make the need for substantial dedicated radiological response capabilities external to the owner-controlled area largely unneeded. If the potential for radiological release outside of the ownercontrolled area can be successfully demonstrated as highly unlikely through accident analysis by the applicant and shown to be confined within the site boundary the need for offsite entities or organizations, including local, state, and federal, could be reduced to a minimal precautionary need. The need for offsite entity response would likely be confined to security incidents and industrial, nonnuclear incident responses; emergency response plans could be dramatically simplified as a result.

\section{EP Standard 10 CFR 50.47(b)(2)}

On-shift facility licensee responsibilities for emergency response are unambiguously defined, adequate staffing to provide initial facility response in key functional areas is maintained at all times, timely augmentation of response capabilities support, and response activities are specified.

Discussion:

Onsite microreactor facility staffing requirements are not known at this time and may vary significantly by plant manufacturer and license. Microreactor operation may be highly autonomous or even remote, which would minimize or eliminate existing fleet staffing requirements and resources except during and after the initial reactor startup. Staff augmentation for emergency response would need to be redefined based on the analysis of credible operational occurrences and their potential consequences.

\section{EP Standard 10 CFR 50.47(b)(3)}

Arrangements for requesting and effectively using assistance resources have been made, arrangements to accommodate State and local staff at the licensee's Emergency Operations Facility have been made, and other organizations capable of augmenting the planned response have been identified.

Discussion:

Due to the low risk of offsite consequences expected of microreactors, the need for an Emergency Operations Facility (EOF) in the immediate area may not be required or, alternatively, could be a shared space with an existing local agency. Any offsite support that is needed would likely be commensurate with the capabilities required for any industrial facility (e.g., fire, medical, law enforcement).

\section{EP Standard 10 CFR 50.47(b)(4)}

A standard emergency classification and action level scheme, the bases of which include facility system and effluent parameters, is in use by the nuclear facility licensee, and State and local response plans call for reliance on information provided by the facility licensees for determinations of minimum initial offsite response measures.

Discussion: 
The four standard emergency classes currently associated with EALs in order of increasing severity are as follows:

- Notification of Unusual Events - This notification "may be initiated by either man-made events or natural phenomena that can be recognized as creating a significant hazard potential that was previously nonexistent. No releases of radioactive material requiring offsite responses are expected."

Situations that lead to this class include:

1. Security threats

2. Natural phenomena

3. Facility emergencies such as a prolonged fire (longer than 15 minutes)

- Alert - This notification would be initiated for events of radiological significance as to require notification of the emergency organization for the specific emergency. Under this class, it is unlikely that offsite response or monitoring would be necessary.

- Site Area Emergency - A site area emergency may be initiated when events such as the major damage of fuel or cladding and actual or imminent failure of fission product barriers is expected. Monitoring at the site boundary should be conducted to assess the need for protective actions. However, because of their very low power level and small source term, this class of alert is not considered plausible and would not be included in the facility emergency plan.

- General Emergency - A general emergency may be initiated by accidents that result in the uncontrolled release of radioactive material. However, because of their very low power level and small source term, this class of alert is not considered plausible and would not be included in the facility emergency plan.

It would be reasonable to assume that the enhanced safety and low consequence potential could allow changes in the structure of EAL currently addressed in 10 CFR 50, Appendix E, Section II.D and NUREG-0654, Rev. 2, Section II.D. While such a change would likely not negate the need for notification and EAL, the existing structure could be maintained with the assumption that the Site Area Emergency and General Emergency alerts are typically implausible and do not require significant planning.

\section{EP Standard 10 CFR 50.47(b)(5)}

Procedures have been established for notification, by the licensee, of State and local response organizations and for notification of emergency personnel by all organizations; the content of initial and follow-up messages to response organizations and the public has been established; and means to provide early notification and clear instruction to the populace within the plume exposure pathway Emergency Planning Zone have been established.

Discussion:

It is anticipated that postulated radioactive releases from credible microreactor accidents will show that offsite radiological doses to the general public will not exceed the EPA PAGs of 1 rem whole body or 5 rem thyroid. The EPZ associated with such a demonstration can also be expected to remain within the facility's exclusion area boundary ([EAB] - owner-controlled property). Therefore, such a facility would not be expected include the General Emergency class of accidents requiring federal assistance as part of the emergency plan. State and local response beyond fire, medical support, and/or law enforcement consistent with an industrial facility would equally not be required. A notification system that informs federal, state, and local organizations (consistent with the emergency action level) could be maintained if desired. 
Procedures will be established for notification to the NRC of any deviation from the facility's technical specifications. Such notification could be provided consistent with 10 CFR 50.72/50.73 (licensee event report) or alternately consistent with the guidance of NRC Information Notice 2009-31, "Nonpower Reactor Licensee Notifications to the NRC During an Incident."

\section{EP Standard 10 CFR 50.47(b)(6)}

\section{Provisions exist for prompt communications among principal response} organizations to emergency personnel and to the public.

Discussion:

It can be presumed that a commercial microreactor design will successfully demonstrate to NRC that postulated radioactive releases from credible incidents associated with facility operation will likely not result in offsite radiological doses to the general public (i.e., exceed the EPA PAGs of 1 rem whole body or 5 rem thyroid.) This in turn allows the EPZ to be defined as not extending beyond the facility's EAB, therefore leading to these facilities being excluded from the General Emergency class of accidents. State and local responses would not be required other than the fire, medical support, and/or law enforcement consistent with a nonnuclear industrial facility.

\section{EP Standard 10 CFR 50.47(b)(7)}

Information is made available to the public on a periodic basis on how they will be notified and what their initial actions should be in an emergency (e.g., listening to a local broadcast station and remaining indoors), the principal points of contact with the news media for dissemination of information during an emergency (including the physical location or locations) are established in advance, and procedures for coordinated dissemination of information to the public are established.

Discussion:

By presuming that a microreactor applicant can successfully demonstrate that postulated radioactive releases from credible incidents will not result in offsite radiological doses to the general public exceeding the EPA PAGs of 1 rem whole body or 5 rem thyroid, the EPZ can be defined as coinciding with the facility's EAB. In such a situation, there would be no required information to be released to the public or news media in the event of accident, because such an accident that triggers notification would not plausibly exist. The licensee/operator may elect to provide information regarding facility operation or condition for public awareness consistent with its established public information policy.

\section{EP Standard 10 CFR 50.47(b)(8)}

\section{Adequate emergency facilities and equipment to support the emergency response are provided and maintained.}

Discussion:

The microreactor design and operation reduce the potential consequences of worse-case scenarios that might lead to adverse radiological consequences to the health and safety of the public or the environment beyond the site boundary. Establishing emergency response facilities (such as an offsite emergency response facility comparable to existing large LWR facilities) would not be necessary if such safety can be successfully demonstrated during a licensing safety assessment. Emergency response equipment for radiological monitoring may still be necessary to assure that no dose limit is exceeded (see EP Standard 10 CFR 50.47(b)(9)).

\section{EP Standard 10 CFR 50.47(b)(9)}


Adequate methods, systems, and equipment for assessing and monitoring actual

or potential offsite consequences of a radiological emergency condition are in

use.

Discussion:

If microreactor applicants can successfully demonstrate that the potential consequences of worse-case scenarios would not lead to adverse radiological consequences to the health and safety of the public or the environment beyond the site boundary, emergency response facilities (such as an offsite emergency response facility comparable to existing large LWR facilities) would be unnecessary. Emergency response equipment for radiological monitoring may be deemed necessary to ensure that dose limits are not exceeded.

\section{EP Standard 10 CFR 50.47(b)(10)}

A range of protective actions has been developed for the plume exposure pathway EPZ for emergency workers and the public. In developing this range of actions, consideration has been given to evacuation, sheltering, and, as a supplement to these, the prophylactic use of potassium iodide (KI), as appropriate. Evacuation time estimates have been developed by applicants and licensees. Licensees shall update the evacuation time estimates on a periodic basis. Guidelines for the choice of protective actions during an emergency, consistent with Federal guidance, are developed and in place, and protective actions for the ingestion exposure pathway EPZ appropriate to the locale have been developed.

Discussion:

Depending on design safety, a range of protective actions will need to be developed for the emergency workers and, if necessary, the surrounding public. Exposure guidelines for onsite workers would be established by facility procedures during operations and emergency situations.

\section{EP Standard 10 CFR 50.47(b)(11)}

Means for controlling radiological exposures, in an emergency, are established for emergency workers. The means for controlling radiological exposures shall include exposure guidelines consistent with EPA Emergency Worker and Lifesaving Activity Protective Action Guides.

Discussion:

Although specific control measures may be adapted to reflect the risks associated with specific designs, radiological exposure controls will be needed onsite and for offsite emergency workers commensurate with their potential for exposure. Licensees must plan to meet applicable exposure guidelines. Offsite emergency worker exposure controls would be limited based on the EPZ plume pathway.

\section{EP Standard 10 CFR 50.47(b)(12)}

Arrangements are made for medical services to contaminated injured individuals.

Discussion:

Facility procedures should provide for the offsite medical services of facility personnel that may be injured or contaminated consistent with the operation of any nuclear and industrial facility. This includes the extent that is required for microreactor facilities that may be remotely operated and/or otherwise may not have onsite staff. While the amount of radioactive material released would undoubtedly be smaller 
than would be expected for a large LWR, the material that is released would still pose a radiological threat requiring possible personnel decontamination and methods for handling and transporting contaminated personnel and material.

\section{EP Standard 10 CFR 50.47(b)(13)}

General plans for recovery and reentry are developed.

Discussion:

General plans for recovery and reentry following a nuclear facility event should typically be addressed by maintenance and repair procedures. However unlikely such an occurrence may be, procedures will need to be developed concerning the containment of any radioactive material that has been dispersed within the EAB.

\section{EP Standard 10 CFR 50.47(b)(14)}

Periodic exercises are (will be) conducted to evaluate major portions of emergency response capabilities, periodic drills are (will be) conducted to develop and maintain key skills, and deficiencies identified as a result of exercises or drills are (will be) corrected.

Discussion:

The emergency plan is expected to describe:

- the initial training and periodic retraining program

- annual onsite emergency drills to be conducted

- provisions for critiques of drills

- development of written scenarios for drills

- biennial review and update of the emergency plan and implementing procedures

- provisions to ensure the operational readiness of emergency communications and emergency health physics equipment

Since no offsite radiological release above regulatory limits is expected for a microreactor operational event, periodic emergency drills would be limited to the personnel and public within the EPZ plume pathway. Emergency drills could be conducted with any onsite personnel in accordance with plant procedures. Plant operations that may be conducted remotely may suggest that no operating personnel may normally be present onsite.

\section{EP Standard 10 CFR 50.47(b)(15)}

Radiological emergency response training is provided to those who may be called on to assist in an emergency.

Discussion:

Periodic emergency drills would be conducted based on the EPZ size and plume pathway. Radiological Emergency response training would be provided to all staff that have a role in emergency response.

\section{EP Standard 10 CFR 50.47(b)(16)}

Responsibilities for plan development and review and for distribution of emergency plans are established, and planners are properly trained.

Discussion: 
Because an emergency plan is required for all sites regardless of accident capability and EPZ size, the responsibilities for plan development and review would be established, and all planning staff would be properly trained.

\section{Summary of Proposed Microreactor Planning Standards 4.1. Enabling Assumptions}

Applicants will satisfactorily demonstrate to NRC during licensing safety assessments:

1. That significant offsite radiological consequences to the public are not a credible event for all normal and off-normal design conditions and, therefore, the reactors would qualify for reduced EP capabilities.

2. That the site will have an EAB that is collocated with or fully contained within the site owner control boundary.

3. That defense-in-depth precautions are in place that effectively ensure that alternative reductions in EP standard requirements will provide an adequate and appropriate reliability of outcomes that preclude public risks.

4. That onsite EP capabilities will adequately cover plausible event contingencies that include fire, medical, and law enforcement responses.

\subsection{Changes to Regulatory Guidance and Requirements}

As was noted in the proposed rule for emergency planning for SMRs and ONTs, if a license applicant adequately demonstrates that a plume exposure pathway EPZ can be established at the site boundary, the NRC would not necessarily mandate offsite radiological emergency planning activities for that site. NUREG-0396 provides this exemption for reactors with power levels less than $250 \mathrm{MW}_{\text {th }}$ to have reduced EPZ sizes. Given that EPZs for microreactors are not expected to extend beyond the facility exclusion area, it is appropriate to presume that the need for substantive offsite emergency planning responses will not be required as well as substantially reducing the onsite emergency planning response needs.

If such an EPZ can be approved, a revised emergency planning standards structure could be developed similar to those that follow in Table 1 below: 
Table 1. Suggested 10 CFR 50.47 Emergency Planning Standards for Microreactor Technologies.

\begin{tabular}{|c|c|c|}
\hline Current Planning Standard & Basis for Change & $\begin{array}{c}\text { Proposed Microreactor } \\
\text { Planning Standard }\end{array}$ \\
\hline $\begin{array}{l}\$ 50.47(b)(1): \text { Assignment of } \\
\text { responsibility (organizational } \\
\text { control) } \\
\text { Primary responsibilities for } \\
\text { emergency response by the } \\
\text { nuclear facility licensee and by } \\
\text { state and local organizations } \\
\text { within the EPZs have been } \\
\text { assigned, the emergency } \\
\text { responsibilities of the various } \\
\text { supporting organizations have } \\
\text { been specifically established, } \\
\text { and each principal response } \\
\text { organization has staff to respond } \\
\text { and to augment its initial } \\
\text { response on a continuous basis. }\end{array}$ & $\begin{array}{l}\text { With minimal source terms, the } \\
\text { licensee emergency response } \\
\text { organizational structure can be } \\
\text { greatly simplified and refocused } \\
\text { on risk factors specific to the } \\
\text { microreactor technology. } \\
\text { Offsite emergency response } \\
\text { organizational structures can be } \\
\text { reduced, due to smaller impact } \\
\text { zones and fewer affected } \\
\text { jurisdictions. If radiological risks } \\
\text { are demonstrated to be minimal, } \\
\text { offsite emergency responses } \\
\text { could emphasize non-radiological } \\
\text { (industrial) scenarios. }\end{array}$ & $\begin{array}{l}\text { No change in Planning Standard } \\
\text { Emergency organizational } \\
\text { control will still be required for } \\
\text { the capabilities needed for onsite } \\
\text { and offsite responses to the } \\
\text { hazards associated with the } \\
\text { licensed facility. However, if the } \\
\text { EPZ is confined to the site } \\
\text { boundary, offsite organizational } \\
\text { planning may become negligible. } \\
\text { Allowances should be provided } \\
\text { for removing the offsite } \\
\text { applications associated with this } \\
\text { EP standard from sites without } \\
\text { an EPZ that extends beyond the } \\
\text { site boundary. }\end{array}$ \\
\hline $\begin{array}{l}\$ 50.47(b)(2) \text { : Onsite emergency } \\
\text { organization } \\
\text { On-shift facility licensee } \\
\text { responsibilities for emergency } \\
\text { response are unambiguously } \\
\text { defined, adequate staffing to } \\
\text { provide initial facility accident } \\
\text { response in key functional areas } \\
\text { is maintained at all times, timely } \\
\text { augmentation of response } \\
\text { capabilities is available, and the } \\
\text { interfaces among various onsite } \\
\text { response activities and offsite } \\
\text { support and response activities } \\
\text { are specified. }\end{array}$ & $\begin{array}{l}\text { On-shift staffing requirements } \\
\text { will be reduced and derived from } \\
\text { the job task functions needed to } \\
\text { support reactor design and } \\
\text { operation. Staff augmentation } \\
\text { needs will likely be lower as well. } \\
\text { Required response times are } \\
\text { expected to increase. } \\
\text { On-shift emergency response } \\
\text { capabilities must still adequately } \\
\text { address initial facility responses } \\
\text { for the design (even if remotely } \\
\text { operated). Timely staff } \\
\text { augmentation may be secured } \\
\text { from offsite resources if response } \\
\text { times allow. }\end{array}$ & $\begin{array}{l}\text { Revise Planning Standard } \\
\text { Onsite emergency response } \\
\text { organization } \\
\text { On-shift facility licensee } \\
\text { responsibilities for emergency } \\
\text { response are unambiguously } \\
\text { defined and enabled with } \\
\text { adequate resources. Ensure that } \\
\text { adequate staffing is available to } \\
\text { address initial facility accident } \\
\text { responses in key functional } \\
\text { areas that assure safe design } \\
\text { conditions are met. Onsite } \\
\text { and/or offsite response } \\
\text { capability augmentation will be } \\
\text { available as needed to ensure } \\
\text { public safety under all normal } \\
\text { and off-normal design } \\
\text { conditions. }\end{array}$ \\
\hline $\begin{array}{l}\S 50.47(b)(3): \text { Emergency } \\
\text { response support and resources } \\
\text { Arrangements for requesting and } \\
\text { effectively using assistance } \\
\text { resources have been made, }\end{array}$ & $\begin{array}{l}\text { It is expected that offsite fire, law } \\
\text { enforcement, and ambulance } \\
\text { services may be needed } \\
\text { commensurate with other } \\
\text { (nonnuclear) industrial facilities } \\
\text { and be the primary response } \\
\text { capability. }\end{array}$ & $\begin{array}{l}\text { Revise Planning Standard } \\
\text { Emergency response support } \\
\text { and resources } \\
\text { Arrangements for requesting and } \\
\text { securing effective assistance }\end{array}$ \\
\hline
\end{tabular}




\begin{tabular}{|c|c|c|}
\hline $\begin{array}{l}\text { arrangements to accommodate } \\
\text { State and local staff at the } \\
\text { licensee's near-site Emergency } \\
\text { Operations Facility have been } \\
\text { made, and other organizations } \\
\text { capable of augmenting the } \\
\text { planned response have been } \\
\text { identified. }\end{array}$ & $\begin{array}{l}\text { A microreactor licensee will seek } \\
\text { to use an existing (non-licensee } \\
\text { owned) near-site EOF for offsite } \\
\text { response control. }\end{array}$ & $\begin{array}{l}\text { resources have been made, } \\
\text { arrangements to accommodate } \\
\text { response staff at a near-site } \\
\text { EOF have been made, and other } \\
\text { organizations capable of } \\
\text { augmenting planned responses } \\
\text { have been identified. }\end{array}$ \\
\hline $\begin{array}{l}\$ 50.47(b)(4) \text { : Emergency } \\
\text { classification system } \\
\text { A standard emergency } \\
\text { classification and action level } \\
\text { scheme, the bases of which } \\
\text { include facility system and } \\
\text { effluent parameters, is in use by } \\
\text { the nuclear facility licensee, and } \\
\text { State and local response plans } \\
\text { call for reliance on information } \\
\text { provided by facility licensees for } \\
\text { determinations of minimum } \\
\text { initial offsite response measures. }\end{array}$ & $\begin{array}{l}\text { The four levels of emergency } \\
\text { classification remain intact, i.e., } \\
\text { 1. Notification of Unusual Event } \\
\text { 2. Alert } \\
\text { 3. Site Area Emergency } \\
\text { 4. General Emergency } \\
\text { General Emergency (and perhaps } \\
\text { Site Area Emergency) conditions } \\
\text { are not expected to be met by } \\
\text { standard microreactor designs. }\end{array}$ & $\begin{array}{l}\text { No change in Planning Standard } \\
\text { The existing classification } \\
\text { system can be applied with } \\
\text { general recognition that Site } \\
\text { Area Emergencies and General } \\
\text { Emergency conditions are likely } \\
\text { implausible events that do not } \\
\text { require emergency planning. }\end{array}$ \\
\hline $\begin{array}{l}\S 50.47(b)(5) \text { : Notification } \\
\text { methods and procedures } \\
\text { Procedures have been } \\
\text { established for notification, by } \\
\text { the licensee, of State and local } \\
\text { response organizations and for } \\
\text { notification of emergency } \\
\text { personnel by all organizations; } \\
\text { the content of initial and follow- } \\
\text { up messages to response } \\
\text { organizations and the public has } \\
\text { been established; and means to } \\
\text { provide early notification and } \\
\text { clear instruction to the populace } \\
\text { within the plume exposure } \\
\text { pathway Emergency Planning } \\
\text { Zone have been established. }\end{array}$ & $\begin{array}{l}\text { This EP standard will not apply to } \\
\text { installations that do not have an } \\
\text { EPZ beyond the site boundary. } \\
\text { For those sites with an offsite } \\
\text { EPZ, the number of participating } \\
\text { agencies and jurisdictions will be } \\
\text { defined by zone size. Sites with } \\
\text { reduced EPZ size should benefit } \\
\text { from commensurately reduced } \\
\text { notification requirements, but } \\
\text { these requirements will not be } \\
\text { eliminated. }\end{array}$ & $\begin{array}{l}\text { Revise Planning Standard } \\
\text { Notification methods and } \\
\text { procedures for offsite impacts } \\
\text { Procedures have been } \\
\text { established for notification, by } \\
\text { the licensee, of state and local } \\
\text { response organizations and for } \\
\text { notification of emergency } \\
\text { personnel by all organizations } \\
\text { (in accordance with the } \\
\text { emergency action level); the } \\
\text { content of initial and follow-up } \\
\text { messages to response } \\
\text { organizations and the public has } \\
\text { been established; and the means } \\
\text { to provide early notification and } \\
\text { clear instruction to the } \\
\text { potentially affected populace } \\
\text { within the plume exposure } \\
\text { pathway Emergency Planning } \\
\text { Zone have been established. }\end{array}$ \\
\hline $\begin{array}{l}\S 50.47(b)(6) \text { : Emergency } \\
\text { communications } \\
\text { Provisions exist for prompt } \\
\text { communications among } \\
\text { principal response organizations }\end{array}$ & $\begin{array}{l}\text { The need for prompt notification } \\
\text { and supporting systems is reduced } \\
\text { or eliminated because the } \\
\text { potential for significant release of } \\
\text { radioactive material is likely to be }\end{array}$ & $\begin{array}{l}\text { Eliminate Planning Standard } \\
\text { Plans for emergency } \\
\text { communications will be } \\
\text { developed (as required by safety }\end{array}$ \\
\hline
\end{tabular}




\begin{tabular}{|c|c|c|}
\hline $\begin{array}{l}\text { to emergency personnel and to } \\
\text { the public. }\end{array}$ & $\begin{array}{l}\text { reduced or absent. This } \\
\text { requirement can be presumed } \\
\text { addressed under } \$ 50.47(b)(5) \text {. }\end{array}$ & $\begin{array}{l}\text { analysis) under } \$ 50.47(b)(5) \\
\text { Notification methods and } \\
\text { procedures for offsite impacts. }\end{array}$ \\
\hline $\begin{array}{l}\text { \$50.47(b)(7): Public education } \\
\text { and information } \\
\text { Information is made available to } \\
\text { the public on a periodic basis on } \\
\text { how they will be notified and } \\
\text { what their initial actions should } \\
\text { be in an emergency (e.g., } \\
\text { listening to a local broadcast } \\
\text { station and remaining indoors), } \\
\text { the principal points of contact } \\
\text { with the news media for } \\
\text { dissemination of information } \\
\text { during an emergency (including } \\
\text { the physical location or } \\
\text { locations) are established in } \\
\text { advance, and procedures for } \\
\text { coordinated dissemination of } \\
\text { information to the public are } \\
\text { established. }\end{array}$ & $\begin{array}{l}\text { Information dissemination needs } \\
\text { are dramatically reduced due to } \\
\text { the smaller plume exposure EPZ } \\
\text { potential. Any information } \\
\text { required to be distributed to the } \\
\text { public could be initially } \\
\text { distributed during licensing and } \\
\text { periodically reinforced and } \\
\text { updated thereafter in conjunction } \\
\text { with existing public emergency } \\
\text { response service announcements } \\
\text { and programs. Installations } \\
\text { without an offsite EPZ would not } \\
\text { be required to deliver periodic } \\
\text { information to the public. }\end{array}$ & $\begin{array}{l}\text { Eliminate Planning Standard } \\
\text { Microreactor public education } \\
\text { and information actions could be } \\
\text { an added component to existing } \\
\text { state and local education and } \\
\text { emergency response plans. } \\
\text { Public education and } \\
\text { information items would operate } \\
\text { in conformance with applicable } \\
\text { state and local requirements. }\end{array}$ \\
\hline $\begin{array}{l}\S 50.47(b)(8) \text { : Emergency } \\
\text { facilities and equipment } \\
\text { Adequate emergency facilities } \\
\text { and equipment to support the } \\
\text { emergency response are } \\
\text { provided and maintained. }\end{array}$ & $\begin{array}{l}\text { Equipment must be provided, } \\
\text { adequate and appropriate to the } \\
\text { risks posed by the installation, but } \\
\text { needs would be lessened due to } \\
\text { safer designs. Potential to } \\
\text { consolidate Technical Support } \\
\text { Center (TSC) and EOF into a } \\
\text { single facility, due to a lessened } \\
\text { and more reasonable timing of } \\
\text { emergency response actions; TSC } \\
\text { and EOF could be combined with } \\
\text { existing collocated facilities. }\end{array}$ & $\begin{array}{l}\text { No change in Planning Standard } \\
\text { It should be recognized, } \\
\text { however, that radiological } \\
\text { response equipment and } \\
\text { facilities would be needed at } \\
\text { levels commensurate with the } \\
\text { risks posed by the installation. } \\
\text { Fire, security, and medical } \\
\text { response capabilities from } \\
\text { state/local entities would be still } \\
\text { needed. }\end{array}$ \\
\hline $\begin{array}{l}\$ 50.47(b)(9): \text { Accident } \\
\text { assessment } \\
\text { Adequate methods, systems, and } \\
\text { equipment for assessing and } \\
\text { monitoring actual or potential } \\
\text { offsite consequences of a } \\
\text { radiological emergency } \\
\text { condition are in use. }\end{array}$ & $\begin{array}{l}\text { Assessment of accidents will still } \\
\text { be required. }\end{array}$ & $\begin{array}{l}\text { No change in Planning Standard } \\
\text { Assessment of accidents will still } \\
\text { be a required capability of } \\
\text { licensees. }\end{array}$ \\
\hline $\begin{array}{l}\oint 50.47(b)(10) \text { : Protective } \\
\text { response } \\
\text { A range of protective actions has } \\
\text { been developed for the plume }\end{array}$ & $\begin{array}{l}\text { This standard is required for sites } \\
\text { having an offsite EPZ. Limited } \\
\text { offsite protective actions are } \\
\text { needed, due to a smaller plume } \\
\text { exposure EPZ. Installations }\end{array}$ & $\begin{array}{l}\text { Revise Planning Standard } \\
\text { Protective response }\end{array}$ \\
\hline
\end{tabular}




\begin{tabular}{|c|c|c|}
\hline $\begin{array}{l}\text { exposure pathway EPZ for } \\
\text { emergency workers and the } \\
\text { public. In developing this range } \\
\text { of actions, consideration has } \\
\text { been given to evacuation, } \\
\text { sheltering, and, as a supplement } \\
\text { to these, the prophylactic use of } \\
\text { potassium iodide, as } \\
\text { appropriate. Guidelines for the } \\
\text { choice of protective actions } \\
\text { during an emergency, consistent } \\
\text { with federal guidance, are } \\
\text { developed and in place, and } \\
\text { protective actions for the } \\
\text { ingestion exposure pathway EPZ } \\
\text { appropriate to the locale have } \\
\text { been developed. }\end{array}$ & $\begin{array}{l}\text { without an offsite EPZ need not } \\
\text { provide EP for an offsite } \\
\text { protective response. } \\
\text { This standard should be amended } \\
\text { to allow for protective responses } \\
\text { commensurate with risks } \\
\text { associated with the design. } \\
\text { However, the standard can be } \\
\text { deleted for designs where a safety } \\
\text { assessment shows an EPZ beyond } \\
\text { the EAB is unnecessary. }\end{array}$ & $\begin{array}{l}\text { For installations requiring an } \\
\text { offsite EPZ, a range of } \\
\text { protective actions has been } \\
\text { developed for the plume } \\
\text { exposure pathway EPZ for } \\
\text { emergency workers and the } \\
\text { public. This range of actions } \\
\text { should consider the need for } \\
\text { evacuation, sheltering, and } \\
\text { prophylactic use of potassium } \\
\text { iodide. Guidelines for the choice } \\
\text { of protective actions during an } \\
\text { emergency are developed and in } \\
\text { place. Protective actions for the } \\
\text { ingestion exposure pathway EPZ } \\
\text { are developed and appropriate } \\
\text { to the locale. }\end{array}$ \\
\hline $\begin{array}{l}\S 50.47(b)(11) \text { : Radiological } \\
\text { exposure control } \\
\text { Means for controlling } \\
\text { radiological exposures, in an } \\
\text { emergency, are established for } \\
\text { emergency workers. The means } \\
\text { for controlling radiological } \\
\text { exposures shall include exposure } \\
\text { guidelines consistent with EPA } \\
\text { Emergency Worker and } \\
\text { Lifesaving Activity Protective } \\
\text { Action Guides. }\end{array}$ & $\begin{array}{l}\text { Standard still required onsite. } \\
\text { Fewer offsite requirements would } \\
\text { exist for smaller plume exposure } \\
\text { EPZ. }\end{array}$ & $\begin{array}{l}\text { Retain Planning Standard } \\
\text { Although specific control } \\
\text { measures may be adapted to } \\
\text { reflect design risks, radiological } \\
\text { exposure controls will be needed } \\
\text { onsite and for offsite emergency } \\
\text { workers commensurate with } \\
\text { their potential for exposure. } \\
\text { Licensees must plan to meet } \\
\text { applicable exposure guidelines. }\end{array}$ \\
\hline $\begin{array}{l}\S 50.47(b)(12): \text { Medical and } \\
\text { public health support } \\
\text { Arrangements are made for } \\
\text { medical services for } \\
\text { contaminated injured } \\
\text { individuals. }\end{array}$ & $\begin{array}{l}\text { Standard still required onsite. } \\
\text { Offsite support will be less due to } \\
\text { the smaller impact zone and } \\
\text { consequently fewer jurisdictions. }\end{array}$ & $\begin{array}{l}\text { No change in Planning Standard } \\
\text { Planning still required for } \\
\text { medical support to contaminated } \\
\text { injured individuals either onsite } \\
\text { or offsite. }\end{array}$ \\
\hline $\begin{array}{l}\S 50.47(b)(13): \text { Recovery and } \\
\text { reentry planning and post- } \\
\text { accident operations } \\
\text { General plans for recovery and } \\
\text { reentry are developed. }\end{array}$ & $\begin{array}{l}\text { ns for recovery and } \\
\text { mensurate with }\end{array}$ & $\begin{array}{l}\text { No change in Planning Standard } \\
\text { Recovery, reentry, and } \\
\text { operations plans will be needed } \\
\text { commensurate with the design } \\
\text { and plant procedures. }\end{array}$ \\
\hline $\begin{array}{l}\$ 50.47(b)(14): \text { Exercises and } \\
\text { drills }\end{array}$ & $\begin{array}{l}\text { More limited scope for onsite and } \\
\text { participating offsite } \\
\text { agencies/jurisdictions due to } \\
\text { smaller EPZ. }\end{array}$ & $\begin{array}{l}\text { No change in Planning Standard } \\
\text { While exercises will be more } \\
\text { limited as a result of lesser } \\
\text { emergency response needs, those }\end{array}$ \\
\hline
\end{tabular}




\begin{tabular}{|c|c|c|}
\hline $\begin{array}{l}\text { portions of emergency response } \\
\text { capabilities, periodic drills are } \\
\text { (will be) conducted to develop } \\
\text { and maintain key skills, and } \\
\text { deficiencies identified as a result } \\
\text { of exercises or drills are (will } \\
\text { be) corrected. }\end{array}$ & & $\begin{array}{l}\text { capabilities that are still required } \\
\text { must be periodically exercised } \\
\text { commensurate with the need for } \\
\text { such capabilities. }\end{array}$ \\
\hline $\begin{array}{l}\$ 50.47(b)(15) \text { Radiological } \\
\text { emergency response training }\end{array}$ & Fewer onsite requirements. & No change in Planning Standard \\
\hline $\begin{array}{l}\text { Radiological emergency } \\
\text { response training is provided to } \\
\text { those who may be called on to } \\
\text { assist in an emergency. }\end{array}$ & $\begin{array}{l}\text { Offsite requirements limited to } \\
\text { fire/rescue/medical and affected } \\
\text { jurisdiction. }\end{array}$ & $\begin{array}{l}\text { While less radiological response } \\
\text { training will be required, } \\
\text { required radiological emergency } \\
\text { response staff must be properly } \\
\text { trained. }\end{array}$ \\
\hline $\begin{array}{l}\S 50.47(b)(16): \text { Responsibilities } \\
\text { for emergency planning }\end{array}$ & $\begin{array}{l}\text { Less onsite effort is required to } \\
\text { maintain plans and program. }\end{array}$ & No change in Planning Standard \\
\hline $\begin{array}{l}\text { Responsibilities for plan } \\
\text { development and review and for } \\
\text { distribution of emergency plans } \\
\text { are established, and planners } \\
\text { are properly trained. }\end{array}$ & $\begin{array}{l}\text { Offsite is integrated into all- } \\
\text { hazards planning, instead of } \\
\text { unique REP plans as discussed in } \\
\text { Appendix A. }\end{array}$ & $\begin{array}{l}\text { While less emergency planning } \\
\text { resources will be required and } \\
\text { may be combined with all- } \\
\text { hazards planning, that capability } \\
\text { must be identified and capable. }\end{array}$ \\
\hline
\end{tabular}

\subsection{Next Steps}

This report provides a description of current EP standards and details why many elements of the current standards are not appropriate for microreactors. Alternative emergency planning standards are proposed for microreactors for industry and NRC consideration. This report does not provide an explicit evaluation of the NRC's proposed rulemaking on emergency planning for SMRs and ONTs (also known as 10 CFR 50.160). However, licensees and applicants will have the option to choose between existing standards and, once finalized and published, the proposed rulemaking of 10 CFR 50.160. Should an applicant choose to use existing regulations, this report discusses the changes in the EP standards that should be considered.

The commercial success of microreactor designs are assumed to be a function of the incorporation of elements and features that provide a low probability of core damage and, in the event of a core damage accident, a high assurance of containment integrity and low offsite dose. Given that the accident source terms associated with microreactors are projected to be significantly lower than those for large LWRs, revisions to emergency planning requirements (e.g., simplification of requirements) are justified. This justification may require considerable technical analysis associated with source term calculations and EPZ plume exposure pathways. A graded approach to implementing emergency planning guidance should be used to appropriately structure microreactor emergency planning requirements by focusing on the unique attributes and technological advantages associated with microreactor designs. 


\section{References}

Code of Federal Regulations Part 50 (10 CFR 50) Section 50.47, “Emergency Plans.”

Code of Federal Regulations Part 50 (10 CFR 50) Appendix E, "Emergency Planning and Preparedness for Production and Utilization Facilities."

EPA PAG guidance (issued in 1992 as EPA-400-R-91-001 Protective Action Guide (PAG) Manual).

EPA, "PAG Manual: Protective Action Guides and Planning Guidance for Radiological Incidents (2017 PAG Manual)," EPA-400/R-17/001, January 2017.

NRC, ACRS letter October 19, 2018.

NRC, Draft Interim Staff Guidance (ISG) 029, "Environmental Considerations Associated with Micro-Reactors," 85 FR 11127, Docket ID: NRC-2020-0051 (ML20054B832).

NRC, FRN 7590-01-P, "Emergency Preparedness for Small Modular Reactors and Other New Technologies," Proposed Rule, docket ID: NRC-2015-0225.

NRC, Information Notice (IN) 2009-31, "Nonpower Reactor Licensee Notifications to the NRC During an Incident," December 10, 2009 (ML092680467).

NRC, NUREG-0396, EPA 520/1-78-016, "Planning Basis for the Development of State and Local Government Radiological Emergency Response Plans in Support of Light Water Nuclear Power Plants," 1978 (ML12188A053).

NRC, NUREG-0654/FEMA-REP-1, R2, "Criteria for Preparation and Evaluation of Radiological Emergency Response Plans and Preparedness in Support of Nuclear Power Plants, December 2019," (ML19347D139).

NRC, NUREG-0696, "Functional Criteria for Emergency Response Facilities, February 1981," (ML051390358).

NRC, NUREG-0800, "Standard Review Plan for the Review of Safety Analysis Reports for Nuclear Power Plants - LWR Edition." Section 13.3, "Emergency Planning, R-3, March 2007," (ML063410307).

NRC, NUREG-0849, "Standard Review Plan for Review and Evaluation of Emergency Plans for Research and Test Reactors." October 31, 1983 (ML062190191).

NRC, RG 1.101, "Emergency Response Planning and Preparedness for Nuclear Power Reactors, R-5, June 2005,” (ML050730286).

NRC, RG 2.6, Rev. 2, "Emergency Planning for Research and Test Reactors and Other NonPower Production and Utilization Facilities," September 2017 (ML17263A472).

NRC, RG 4.7, R3, "General Site Suitability Criteria for Nuclear Power Stations," (March 2014).

NRC, "Rulemaking for Emergency Preparedness for Small Modular Reactors and Other New Technologies (docket ID: NRC-2015-0225),” (ML16309A332).

NRC, SECY-11-0152, "Development of an Emergency Planning and Preparedness Framework for Small Modular Reactors," October 28, 2011. 
NRC, SECY-18-0103, "Emergency Preparedness for Small Modular Reactors and Other Nuclear Technologies,” Proposed Rule, docket ID: NRC-2015-0225 (ML18134A076).

Oklo, "Oklo Power Combined Operating License Application for the Aurora at INL," NRC Docket No. 99902046, ADAMS Accession No. ML20075A000, March 2020. 